\title{
HUMOROUS ELEMENTS AND TRANSLATION IN ANIMATED FEATURE FILMS: DREAMWORKS (2001-2012)
}

\author{
Rebeca Cristina López González \\ rebecalopez@uvigo.es \\ Universidade de Vigo
}

\begin{abstract}
This paper will present some of the results stemming from the thesis La alusion como fuente de creación de humor y su traducción: análisis del cine de animación de DreamWorks (2001-2012) (López González 2015). This study had as its main objective the analysis of intertextual humour in fourteen DreamWorks animated feature films to reveal which are the humorous elements (Martínez Sierra 2008) used in the creation of humour. A definition of intertextual humour will be provided as well as details related to how Martinez Sierra's classification of humorous elements was applied to the study of animation. The results obtained will show how humour can be triggered for audiences of all ages from the original version films. In order to reach the Spanish target audience these films were dubbed and subtitled into Spanish. Here, attention will be paid to the dubbing process and three examples of how humour has been translated within some of the categories described by Martínez Sierra will be commented on.
\end{abstract}

\section{Resumen}

Este trabajo presenta algunos de los resultados extraídos de la tesis La alusión como fuente de creación de humor y su traducción: análisis del cine de animación de DreamWorks (2001-2012) (2015). Este estudio tiene por objetivo principal el análisis del humor intertextual empleado en catorce películas de cine de animación de DreamWorks, con el propósito de desvelar cuáles son los elementos humorísticos (Martínez Sierra 2008) a los que se recurre para crear humor. Por otra parte, este trabajo proporcionará una definición de humor intertextual, así como una serie de aspectos relacionados con la aplicación del modelo de Martínez Sierra al estudio del cine de animación. Los resultados obtenidos nos mostrarán cómo se consigue un tipo de humor destinado a todos 
los públicos en las películas en su versión original. Con la finalidad de llegar al público español, estas películas se doblaron y subtitularon al español peninsular. El proceso de doblaje cobrará especial importancia en este estudio, y se presentarán tres ejemplos de cómo el humor se ha traducido, atendiendo a las categorías humorísticas descritas.

Key Words: Humour. Dubbing. Intertextuality. Humorous elements. Animation.

Palabras clave: Humor. Doblaje. Intertextualidad. Elementos humorísticos. Animación.

Manuscript received on June 30, 2016 and accepted for publication on November 16, 2016.

Para enlazar con este artículo / To link to this article:

http://dx.doi.org/10.6035/MonTI.2017.9.10

Para citar este artículo / To cite this article:

LÓPEZ GonZÁlEZ, Rebeca Cristina. (2017) "Humorous elements and translation in animated feature films: DreamWorks (2001-2012)." In: Martínez Sierra, Juan José \& Patrick Zabalbeascoa Terran (eds.) 2017. The Translation of Humour / La traducción del humor. MonTI 9, pp. 279-305. 


\section{Defining Humour and Intertextual Humour}

In order to provide a definition of humour, at least three words must be included: entertainment, laughter and amusement. Vandaele (2010: 147) has noted that "at first glance, humour is easy to define. Humour is what causes amusement, mirth, a spontaneous smile and laughter." Humour is a trait assigned to humans, a human phenomenon: "Humour is human. Why? Well, because the philosopher, Aristotle, says so." (Critchley 2002: 25). Nevertheless, laughter is not to be seen as proper or exclusive to human beings since it has been studied in animals as a call for social play. However, laughter has allowed group cohesion and the creation of an identity during our evolution as a species.

In addition, laughter means that some sort of content has been created and mediated symbolically by a recipient. This content may generate a surprise, an uncertainty or insight making an audience laugh. According to Vandaele, it is through our symbolic mind that we can "turn uncertainty, surprise and danger into what we call humour" (Vandaele 2010: 148).

The nature of humour can be defined and described from a holistic point of view. Raskin provides an explanation of this phenomenon by enumerating the most relevant thoughts in the field developed over centuries:

[a]s a ridicule of a human fault or error, but not too serious, because then it would not be an appropriate cause for laughter (Aristotle), as an exhibition of superiority over somebody else but again, not too serious (Stendhal), as an attempt to abase, denigrate a person or a cause of high stature (Bain) or to lower a value (Propp, Stern), as a metamorphosis of tense expectation into nothing (Kant), as a switch of one's mind and attention from something big and significant to something small and insignificant (Spencer), as an incongruent treatment of things, in deviation from the customary norm (Hegel, Schopenhauer). The purely human character of humour was somewhat chauvinistically emphasized (Bergson) -a property humour seems to share with lying (1979: 326).

Vandaele (2002a: 153) has also noted that humour is part of our linguistic exchanges, to the point that we hardly notice its presence in our daily routines: "Humour is used in everyday parlance to refer simultaneously to an effect 
and its (con)textual causes, an occurrence so normal(ized) that we don't even notice it." Based on this definition, humour can be considered an effect (Chiaro 1992: 5, Bruździak 2011: 3) expressed verbally and non-verbally.

Spanakaki's interpretation of this concept helps focus attention on the main areas to be studied in this paper, namely; culture and intercultural communication, mass entertainment and cinema products, humour and audiovisual translation (AVT):

Humour is an essential part of the everyday component of innumerable literary works and films and of art in general. It is rooted in a specific cultural and linguistic context, but it is also an indispensable part of intercultural communication and mass entertainment (2007: n. p.).

Humour has been considered as a constituent of artistic production and matter worthy of rigorous research since the end of the 80's (see the journal Meta 1989, Chiaro 1992, Vandaele 2001). However, this interest has only made the definition of humour more problematic owing to the lack of a terminological consensus leading to a range of different definitions, some of which have been referred to above. For this reason, defining humour depends upon the purpose for which it is used, as Attardo (1994: 4) has pointed out. For example, literary criticism demands a detailed categorisation of this concept, whereas linguists have made broader definitions the starting point of their research, basing analysis on whatever seems to be funny or makes us laugh. Humour is deduced based on the effect it produces. The pragmatic approach has resulted in a more useful discussion by interpreting humour as a text whose perlocutionary or intended effect is laughter.

\subsection{Intertextual Humour and Allusive Jokes}

Certain kinds of humour require extra knowledge belonging to a community, nation or culture. In order to get the joke it is not enough to understand the language in which it has been uttered; it is not a question of understanding the meaning of each of the words used to create any verbal joke. Extra information is required; this is the secret code or, in more formal terms, what is known as the concept of shared knowledge or the suggested encyclopaedia in Eco's words (1981: 112). As Critchley (2002: 68) puts it, "native speakers are [endowed] with a palpable sense of their cultural distinctiveness or even superiority. In this sense, having a common sense of humour is like sharing a secret code."

When a humorous situation is highly culture-specific its power to amuse often loses strength or even disappears beyond the culture of origin. Chiaro's words clearly summarise this idea: "Verbal humour travels badly" (2010: 1), to which she adds 
As it crosses geographic boundaries humour has to come to terms with linguistic and cultural elements, which are often only typical of the source culture from which it was produced thereby losing its power to amuse in the new location (Chiaro 2010: 1).

Nash attributes this power to certain elements which have been carefully arranged in a structure to play with various dualities (ambiguity, polysemy, statement and implications), thus elaborating a joke. These elements need to be understood together with their charge, be it according to Nash: "cultural and social facts, about shared beliefs and attitudes, about the pragmatic bases of communication." (1987: 9). This expert in humour affirms that

Humour is not for babes, Martians, or congenital idiots. We share our humour with those who have shared our history and who understand our way of interpreting experience. There is a fund of common knowledge and recollection, upon which all jokes draw with instantaneous effect; though indeed to describe the resources of the fund must seem like an undertaking of tedious length (Nash 1987: 9).

The description of part of this fund is precisely what this paper pursues, based on a compilation of the specific cultural and intertextual shared knowledge used by Dreamworks in fourteen animated feature films. This data originally produced in American English usage is part of what Even-Zohar (1997: 355) has referred to as the culture repertoire, understood as "the aggregate of options utilised by a group of people, and by the individual members of the group, for the organisation of life."

This culture repertoire needs to be made because:

although sensed by the members of the group as given, and taken by them for granted, is neither generated nor inherited by our genes, but need be made, learned and adopted by people, that is the members of the group. This making is continuous, although with shifting intensity and volume. On the one hand, it may be made inadvertently (1) by anonymous contributors, whose names and fortune may never be known, but also deliberately, (2) by known members who are openly and dedicatedly engaged in this activity (Even-Zohar 1997: 357).

Allusions simultaneously activate two texts by creating a relation between them, i.e. intertextuality, and function as markers or directional signals. A marker can be identified as the segment or element belonging to an independent text (BenPorat 1978). These texts are circumscribed within a specific culture repertoire from which they are taken in order to create humour. Therefore, allusions can be a rich source of humour (Goatly 2012: 274) and have been classified by Norrick within the interpersonal dimension of conversational joking. As he explains in the introduction to his book Conversational Joking: Humour in 
Everyday Talk, humour cannot be analysed exclusively from the syntactical and semantic point of view: "A description of the syntax and semantics of jokes remains incomplete without an understanding of their interpersonal and social dimensions" (1993: 2).

Norrick has also studied wordplay, discovering that conversations are full of allusions and the re-citation of formulas and phrases from other spoken and written sources. He defines the interpersonal dimension of joking as "the speaker's presentation of a personality through the joke performance and the elicitation of action from and information about the hearer" (1993: 16). As a part of everyday conversation, intertextuality with humorous purposes could be expected to be part of the oral language used in films to be dubbed into other languages. In the case in hand, these films come from the animation industry, more specifically Dreamworks SKG where a lower degree of humorous intertextuality can be expected, taking into account the main audience that these productions are aimed at.

Norrick (1993: 72) describes the way allusions work in conversational joking: a) A funny text can allude to another joke which doubles humorous potential by contributing with witticism to the alluding text and by recalling the original text for the audience in the know; b) Unannounced intertextual references or allusions pose tests to the recipients' understanding.

Allusive jokes reveal relevant social data about the hearers, such as their beliefs, their attitudes, their group membership, etc. and they concentrate the intertextual reference on the punch line, triggering the audience's expected laughter.

In a nutshell, not getting a joke is "due to a certain amount of unshared knowledge between sender and recipient" (Chiaro 1992: 14) and this can be applied to allusive jokes. This sociocultural knowledge might be used in an intertextual way by relating one text (discourse) to one or several texts (discourses). Humorous intertextuality also appears in a text (discourse) where allusions, quotations, references, proverbs, parodies and satire related to other texts are made with the purpose of amusing and making the audience laugh. As del Corral notes

We are wiser than the clown and can anticipate the calamitous results of his stupid actions. We understand a double-entendre because we are clever enough to grasp a word or phrase in more than one sense at the same time. We take pleasure in our ability to identify the allusions of parodies and satire. We are delighted by our astuteness in comprehending what is not spelled out for us, not on the printed page, between the lines (del Corral 1988: 26). 


\section{Theories Regarding Humour and the Classification Applied in this Study}

Three main theories aim to explain the mechanisms of humour: the superiority theory, the relief theory and the incongruity theory. The superiority theory relates laughter caused by our feelings of superiority regarding someone or something else. The relief theory considers laughter as a release of nervous energy. And the third theory is the incongruity theory. Incongruity can happen, according to Vandaele (2010: 148) "when cognitive rules are not being followed." Critchley (2002:3) defines this third theory of humour as the one that includes humour "produced by the experience of a felt incongruity between what we know or expect to be the case, and what actually takes place in the joke, gag, jest or blague."

To these more philosophical theories of humour, one can add the relatively recent linguistic approach, which explains humour through semantics (meaning) and pragmatics (the speaker's intention when uttering a humorous remark). Raskin's script-based semantic theory of humour (1985), Attardo's five-level model for the analysis of joke texts (1989), Attardo and Raskin's General Theory of Verbal Humour (GTVH) (1991) and Ruch, Attardo and Raskin's empirical support of the GTVH (1993) are all worthy of mention, together with the twenty-first century revisions of humour carried out by Vandaele (2002b), Ritchie (2004) and Goatly (2012) among others.

These theories explain how humour is created, but in this paper attention must be paid to the classification used in order to identify the intertextual humour used in the analysed corpus. The following classification together with the comparison of the source text and dubbed version enables the finding of intertextual jokes discussed here. This classification has been extracted from Chaume 2012, who has summarized Martínez Sierra's (2008: 143-153) classification as follows:

Community-and-Institution Elements, which refer to cultural or intertextual features tied to a particular culture such as politicians, celebrities, organisations, newspapers, or films.

Community-Sense-of-Humour Elements, which seem to be more popular in certain communities than in others, such as the typical use of a certain country or region as a subject to raise laughter in another country or region.

Linguistic Elements, i.e. jokes based on wordplay, puns, etc.

Visual Elements that elicit humour through what can be seen on screen.

Graphic Elements, when a written text on screen is humorous.

Paralinguistic Elements, such as non-verbal qualities of voice, certain tones, pitches and ways of speaking associated with recognisable expressions of emotions as well as narrative silences. 
Sound or Acoustic Signs recorded on the soundtrack such as special effects that, by themselves or in combination with others, may raise a smile or laughter.

Non-marked or Miscellaneous Elements that are not easily categorized but are, nevertheless, humorous (Chaume 2012: 149-150).

\section{Dubbing Intertextual Humour}

There is a need to establish a link between humour and intertextuality when translating audiovisual humour. The relationship between these phenomena is essential for the transfer of a wide range of text types, including audiovisual texts. This relationship requires on the part of the translator the identification of intertextual humorous elements in order to transfer these jokes into a target language. To explain this link, we must firstly bear in mind that jokes are constructed based on opposing scripts or incongruities built, in turn, on shared cultural information to generate an incongruous situation. This information helps create membership within a set community able to understand and enjoy the joke. Often, even a slight contextual clue in a joke will interact with the existing socio-linguistic knowledge to generate the whole relevant scene.

As Vandaele (1999: 241) points out, "a great deal of humour involves problem solving." In order to solve the problem posed by a joke, the audience must make an effort. Once this effort has been made the audience feels the joy of understanding the joke, experiencing a feeling of cleverness. According to him, the ability to get the joke increases the audience's self-esteem. Antonopoulou (2004: 245) notes that, "the same applies to recognising an allusion, which also involves relative effort" causing some kind of pleasure in the receiver of the allusion since s/he is able to understand the secret code, or in other words, unravel the allusive mystery.

Moreover, regarding the effort factor under discussion, one of the recipients who has to make an extra effort is the translator, as part of the dubbing agents involved in the transfer of an audiovisual text, because s/he will need to grasp intertextuality with a humorous purpose in a ST (source text) and translate it into the TT (target text).

As part of an audiovisual text, intertextual humour is presented through two channels (the acoustic and visual) and several codes. Both channels and codes are coordinated or synchronized. When a film is dubbed, words and sound are adapted to fit the image, which means that the translator is conditioned by the images on screen. Also, translators must consider the five types of synchrony described by Mayoral et al. (1988: 359) (time, space, content, phonetic and characterization) which restrict translators' scope of action. 
Chiaro's words summarise the challenge posed by audiovisual translation (film translation) and humour:

The main setback regarding translating for film is the fact that screen products are polysemiotic; that is, they transmit messages by means of diverse codes [...]. Viewers watch actors in action and simultaneously listen to what they say. At the same time, viewers read any written information they might see (signs, newspaper headlines, notes, etc.) while also perceiving a variety of sounds (noise from surroundings, for example traffic, birdsong, white noise, etc.; body sounds like breathing, coughing, etc. and background music). Audiences will also be aware of actors' facial expressions and gestures, their dress, make-up and hairstyles; they will take in the scenery and hear songs that may have lyrics that are significant to the storyline of the film. Thus, the verbal elements of filmic products depend heavily on other acoustic features, but above all on a series of visual components to which they are inextricably linked. With regard to verbal humour, when a joke, a gag or a line is linked to the visuals, translation becomes especially difficult (Chiaro 2010: 4-5).

Fuentes (2001: 81) studied the difference between the reception of humour in an everyday social context and its use in audiovisual texts to demonstrate that humour used in audiovisual texts is less spontaneous and pursues an intent quite often related to iconic or sound semiotic elements external to the textual message expressed in the dialogues.

Intention is therefore one of the key words to be considered when dubbing films because, despite the constraints imposed by synchronisation, the director's intent must be transferred during the translation process. With regard to intertextual humour, Fuentes (2001: 70) confirms that intertextuality appears in humorous films, requiring different translation strategies whose effects on the audience vary according to the mode of translation and cultural context. Leading on from Fuentes' remarks, two ideas require further comment. Firstly, he mentions allusions as a way of generating humour, going on to add cultural references as another humorous resource, thereby confirming the theory that both types of references (cultural and intertextual) should be considered as separate entities. Intertextuality is created by the usage of cultural information or knowledge, but cultural references on their own do not constitute an intertextual reference if the interaction between a hypotext and a hypertext does not take place. Secondly, Fuentes notes that different translation strategies are deployed in order to solve translation problems originating in a film. For this reason, there is a need to learn more about the strategies and techniques which can help the translator deal with humour. 


\subsection{Translation Strategies to Dub Intertextual Humour}

Translation studies help identify the steps followed by translators. The descriptive approach allows the creation of guidelines to aid the translator, providing possible solutions to overcome translation difficulties. Through the techniques and strategies described below, dubbing intertextual humour does not become any easier, but at least translators may find these theoretical procedures useful.

Bassnett supplies the translator with the following guidelines, which can be interpreted as a starting point to deal with the intertextual humorous elements inserted in an audiovisual text:

(1) Accept the untranslatability of the source language phrase in the target language on the linguistic level.

(2) Accept the lack of a similar convention in the TL.

(3) Consider the range of TL phrases available, having regard to the presentation, status, age, sex of the speaker, his relationship to the listeners and the context of the meaning in the SL.

(4) Consider the significance of the phrase in its particular context (...).

(5) Replace in the TL the invariant code of the SL phrase in its two referential systems (the particular system of the text and the system of the culture out of which the text has sprung) (1980: 22).

Bearing in mind these initial steps, Fuentes' proposal completes these general strategies with four techniques applied to the translation of humour (addition/ compensation, substitution, metalinguistic procedures and omission):

a) Addition/compensation: of a joke to compensate for another which was not translated.

b) Substitution: one joke for another.

c) Metalinguistic procedures: commentaries, explanations and footnotes.

d) Omission: the humorous episode is not translated (1998: 667, my translation).

However, when dealing with an audiovisual text, and more specifically when the text produced will be orally uttered in the case of a dubbed film, there is no space for comments, footnotes and additional explanations.

The functionalist approach, as seen above, suits the transfer of the intended effect created by humour in a ST. Antonopoulou offers some concluding remarks which work as translation strategies applicable to the transfer of intertextual humour on screen:

The translator of a humorous text (like the translator of a serious one) is implicitly engaged in a multi-factor cost/benefit analysis, which should yield the optimal strategy for the appreciation of a text's humour (unlike the translator of a serious text) by the target readership. In the process s/he has to take into account the differences between the expectations and the cognitive 
environments not only of ST and TT readers, but also of subsets within them (like the translator of a serious text). (...) For the purposes of humour translation, these observations suggest that the target audience is prepared to make some guess work and that this may well be expected to be put to use if they recognize humorous intent with the additional benefits humour recognition involves. The problem for the translator is how much cognitive effort is envisaged in each case (Antonopoulou 2004: 245-246).

Two further strategies can be extracted from this paper. In the first place, what translation studies call norm-related factors, "such as special target language and target group considerations along with the open vs. closed nature of the target language and culture" (Antonopoulou 2004: 246) and the challenge that cultural-specific humour represents through those humorous elements which are "puzzling or impenetrable for the target text reader." Secondly, replacement is the technique suggested to deal with these "culture bumps" (Leppihalme 1997: 197), justified by the fact that TT readers are entitled to "the materials needed for participation in a communicative process" (Leppihalme 1997: 197).

Cuéllar and García have described how humour is dealt with in comedy films. In their article "Cultura y Humour: traductores al borde de un ataque de nervios" (2004), they explain how humour is translated depending on the acceptance of foreign cultural references by the target culture.

Foreign culture-specific references assimilated by the target culture do not demand a great effort on the part of the target audience in order to be understood, whereby the humorous element can be maintained in the translated target text. Two techniques are mentioned in this regard: (1) Reproducing or retaining references which do not require modifications to be understood; and (2) Explicitation, which maintains the essence of the source culture but simplifies the comprehension process required on the part of the target audience. It is often the case that the pragmatic intention of the audiovisual source text becomes diluted due to the not-always-subtle explanation of the humorous content offered to the target audience. Here, Cuéllar and García (2004) suggest that Venuti's (1995) domestication and foreignization should be considered.

The second type of problem posed by the translation of humour with references has been described as references to cultural elements which belong to the source culture but which do not exist in the target culture. The technique suggested in these cases is adaptation, whereby the foreign humorous reference is replaced by a humorous reference known and recognised in the target culture. Six different types of adaptation have been analysed by Cuéllar and García (2004): 
1) Generalisation (hypernymy): A more general term is used with the purpose of removing the unknown referent while maintaining the humorous function of the speech act.

2) Adaptation or naturalisation: This technique broadens the distance between the ST and the TT. The function of the ST is maintained, but the referent changes completely to be easily understood by the audience in order to maintain as far as possible the connotation produced by the original referent in the source audience.

3) Adaptation or naturalisation of a foreign reference: The lack of shared knowledge concerning a specific humorous element requires adaptation as commented above.

4) Adaptation or naturalisation due to the translator's intent to eliminate any element which would be considered external to the target audience.

5) Adaptation or naturalisation of an assimilated or accepted humorous reference with the aim of creating a more natural target text.

6) The terms overtranslation and over-stimulated translation used by Cuéllar and García appear to derive from the concept domestication. Overtranslation/domestication is put into practice with both types of references, i.e. those which have been accepted by the target audience due to the habitus phenomenon, and those which are unfamiliar to the audience. Cuéllar and García are quite critical about this translation method.

Chiaro (2006: 200; 2008: 592; 2010: 6-7) proposes four translational strategies to transfer verbally-expressed humour (VEH) on screen:

Verbal humour on screen tends to be translated in the following ways:

a. Leave the VEH unchanged [...].

b. Replace the source VEH with a different instance of VEH in the TL [...].

c. Replace the source VEH with an idiomatic expression in the TL $[\ldots]$.

d. Ignore the VEH altogether (2010: 6-7).

To end this section, Martínez Sierra's (2008) contribution to the study of humour translation must be mentioned and, more specifically, his opinion regarding the strategies and techniques available to solve humour-on-screen translation problems. Having analysed domestication and foreignization in the translation of humour and cultural references in AVT, Martínez Sierra arrived at the conclusion that when dealing with humour the function of the audiovisual text drives the priorities of the translator. Manipulating the ST is the means to make the target audience laugh, which is the main objective of 
any comedy. Translators cannot offer the target audience a meaningless joke, be it intertextual or not.

\section{The Hypotheses and the Objective}

The theoretical scenario described above has led to the following hypotheses:

- A certain amount of content which appears in audiovisual products aimed at children and adolescents can be labelled as intertextual, requiring a prior knowledge on the part of spectators in order to be understood. This content fulfils a humoristic purpose which needs to be transferred when dubbed. The contrary would result in the non-accomplishment of the target text skopos (Nord 1997) if the functionalist approach is to be considered.

- The non-translation of intertextual humour results in the absence of the joke, a joke which might be sensed in the dubbed version but might not be communicated to the target viewer.

- The objective of this paper will be to exemplify how humour is created in these films and present some examples of how this intertextual humour was dubbed into Spanish applying Martínez Sierra's (2008: 143-153) classification of humorous elements.

\section{Materials and Methodology}

The need to do further research on intertextuality and more specifically on audiovisual intertextual humour aimed at all audiences included in audiovisual products mainly addressed to young audiences has required the selection of a corpus which potentially included this phenomenon.

Animation (and its translation) has been barely studied in Spain and was even considered a minority genre (Yébenes 2002: 84) in film listings until the appearance of DreamWorks' Shrek (2001). Its successful box office results served as a future advertisement of guaranteed entertainment and laughter. It was just a matter of time for DreamWorks to continue producing not only new sequels about the green ogre but also other main characters have obtained the praise of the critics and general public.

Fourteen films were selected to be part of the analysed corpus: Shrek (2001); Shrek 2 (2004); Shark Tale (2004); Madagascar (2005); Over the Hedge (2006); Shrek the Third (2007); Bee Movie (2007); Kung Fu Panda (2008); Madagascar 2: Escape to Africa (2008); Monsters vs. Aliens (2009); Shrek, Happily Ever After (2010); Megamind (2010); Kung Fu Panda 2 (2011); and Madagascar 3: Europe's most wanted (2012). These were chosen from more than twenty-five 
films in their short history of animation, only eighteen years when compared to its pioneer, Disney.

This corpus was compiled based on the following criteria: These films would have to be produced by the same company so that its discourse would be the same in the sense that its vision of reality and contents would be similar despite the variety of themes covered; each of these productions were to be created exclusively in the USA; these films would be computer-generated which is the company's most-often used technique; these productions would be classified under the same genre and subgenre, namely, all of them are animated feature films and comedies (other subgenres which allow the classification of animation are: Adventure, Family, Drama, Musical, Romance, Fantasy, Western, Action and Science Fiction).

In terms of the target text, three more criteria were applied to the corpus; the films were rated in the target culture as General Audience, what is known as a four quadrant film. The agency in charge of dubbing these productions would be the same one, Sonoblok S.A. and some of the voice talents in charge of bringing into life the computerised cartoons in the Spanish culture would be part of this country's star system, just as it had been done in the original version.

This study has been carried out by implementing a methodology which allowed the analysis for each case. These fourteen films have been studied in their English original version and Spanish dubbed version with the aim of comparing the translation of the intertextual humour. The technical information was extracted from DreamWorks film productions for the period 1998 to 2012 and then the corpus was selected based on the criteria described above. In order to spot the different cases of intertextual humour, each film was screened numerous times while data was being collected through transcription and classified into 528 data sheets. In total 1,271 minutes (more than twenty-one hours) were analysed. To locate intertextual humour in both the ST and TT, two sources were extremely helpful, firstly, the IMDB data base online where comments about the humour used in each of the films have been accurately described, and secondly, the producers' and directors' comments which are included in the films' DVD's detailing the influences and instances of homage intended with their work. Many of these comments reveal important intertextual information which otherwise might be obscure for a foreign translator.

Three theoretical frameworks made the classification of the compiled intertextual humour (IH) possible: Type of intertextuality; channels and codes involved in the transmission of the IH; and the type of humour created for each occurrence. The creation of a data sheet for each occurrence helped organise the information extracted from the films, thus favouring the quantitative and 
qualitative analyses, which have been later presented in tables and graphics. These visual representations have been useful to reveal how humour has been created in the source culture and its translation into the Spanish spoken in Spain. Furthermore, the transcription of the occurrences in both languages shows which have been the translation techniques chosen in the dubbing process (adaptation, literality, omission and domestication).

This methodology has proved to be suitable for the aims of this study since a significant number of results has been obtained with regard to how intertextual humour has been created, how jokes might have been omitted or modified from the TT and which humorous elements have been included in these films to make the audience laugh.

\section{Results and Examples}

\subsection{Results obtained from the $S T$}

The total number of compiled occurrences from the fourteen DreamWorks animated feature films amounted to 745 . The following table presents the number of occurrences per original version film:

\begin{tabular}{|c|c|}
\hline FILM & OCCURRENCES/ FILM \\
\hline SHREK (SH1) & 75 \\
\hline SHREK 2 (SH2) & 159 \\
\hline SHARK TALE (ST) & 46 \\
\hline MADAGASCAR (M1) & 42 \\
\hline OVER THE HEDGE (OVT) & 27 \\
\hline SHREK THE THIRD (SH3) & 78 \\
\hline BEE MOVIE (BM) & 73 \\
\hline KUNG FU PANDA (KFP1) & 16 \\
\hline MADAGASCAR 2 (M2) & 32 \\
\hline MONSTERS VS. ALIENS (MVSA) & 32 \\
\hline SHREK: HAPPILY EVER AFTER & 59 \\
\hline (SH4) & 56 \\
\hline MEGAMIND (MGM) & 22 \\
\hline KUNG FU PANDA 2 (KFP2) & 28 \\
\hline MADAGASCAR 3 (M3) & 745 \\
\hline TOTAL FIGURE &
\end{tabular}

Table 1 - Total number of compiled occurrences per film. 
It is worth mentioning those elements which belong to the source text's community and institutions (Martínez Sierra 2008) when discussing the humorous elements used to create some of the intertextually humorous scenes. In fact, one could assume that intertextual humour can only be created thanks to the prior knowledge which specifically belongs to the culture where it is being produced. This study reveals the contrary since a number of occurrences have been found in which intertextual humour is generated through the use of visual, graphic, paralinguistic and musical elements. Some of the examples provided below show some of these unexpected occurrences. Stemming from Martínez Sierra's classification, 745 occurrences have been categorized as follows:

\begin{tabular}{|l|r|r|r|r|r|r|r|r|r|r|r|r|r|r|c|}
\hline & SH1 & SH2 & ST & M1 & OVT & SH3 & BM & KFP1 & M2 & MVSA & SH4 & MGM & KFP2 & M3 & TOTAL \\
\hline TOTAL & & & & & & & & & & & & & & & 745 \\
\hline $\begin{array}{l}\text { COMM. \& } \\
\text { INSTIT. E. }\end{array}$ & 23 & 76 & 14 & 15 & 13 & 35 & 32 & 2 & 19 & 19 & 28 & 21 & 9 & 16 & 322 \\
\hline VISUAL E. & 23 & 21 & 3 & 6 & 2 & 7 & 11 & 9 & 4 & 5 & 4 & 11 & 5 & 4 & 115 \\
\hline MULTIPLE E. & 6 & 35 & 10 & 1 & 3 & 17 & 4 & 0 & 3 & 5 & 13 & 1 & 1 & 1 & 100 \\
\hline GRAPHIC E. & 2 & 10 & 15 & 9 & 2 & 6 & 11 & 0 & 1 & 1 & 1 & 11 & 1 & 2 & 72 \\
\hline MUSICAL E. & 9 & 10 & 4 & 5 & 0 & 8 & 5 & 0 & 4 & 0 & 10 & 10 & 0 & 1 & 66 \\
\hline LINGUISTIC E. & 11 & 4 & 0 & 1 & 4 & 3 & 7 & 4 & 0 & 1 & 3 & 1 & 5 & 2 & 46 \\
\hline $\begin{array}{l}\text { SOUND \& } \\
\text { SIGNALS E. }\end{array}$ & 0 & 2 & 0 & 4 & 2 & 2 & 0 & 1 & 0 & 1 & 0 & 0 & 1 & 1 & 14 \\
\hline $\begin{array}{l}\text { PARALINGUISTIC } \\
\text { E. }\end{array}$ & 0 & 0 & 0 & 1 & 0 & 0 & 2 & 0 & 0 & 0 & 0 & 1 & 0 & 0 & 4 \\
\hline $\begin{array}{l}\text { COMM. } \\
\text { HUMOUR E. }\end{array}$ & 1 & 0 & 0 & 0 & 0 & 0 & 1 & 0 & 0 & 0 & 0 & 0 & 0 & 1 & 3 \\
\hline NON-MARKED E. & 0 & 1 & 0 & 0 & 1 & 0 & 0 & 0 & 1 & 0 & 0 & 0 & 0 & 0 & 3 \\
\hline
\end{tabular}

Table 2 - Intertextual humorous elements per film.

As this table shows, out of the 10 humorous elements categories analysed in this study, four concentrate the highest figures which means that DreamWorks' intertextual humour is created mainly thanks to the following types of elements: Community and Institution Elements (322), Visual Elements (115), Multiple Elements (100) and Graphic Elements (72). Humour is achieved by making reference to other texts and concepts which have been created in the past within the American culture.

Humour is also triggered by combining the set of elements described by Martínez Sierra, resulting in what has been named in this study as the Multiple Element category. One hundred occurrences of this type demonstrate how intertextual humour was built thanks to a rich mixture of elements which certainly put the translator to the test. Visual humour allowed the creation of 
more than a hundred comic situations which do not require a translation into Spanish to be understood. Forty-six occurrences belong to the Linguistic category, which includes those jokes based on verbally expressed humour. Here, the translator will have to participate in the creation of a joke for the Spanish audience. The following graph represents the distribution of these humorous elements per film:

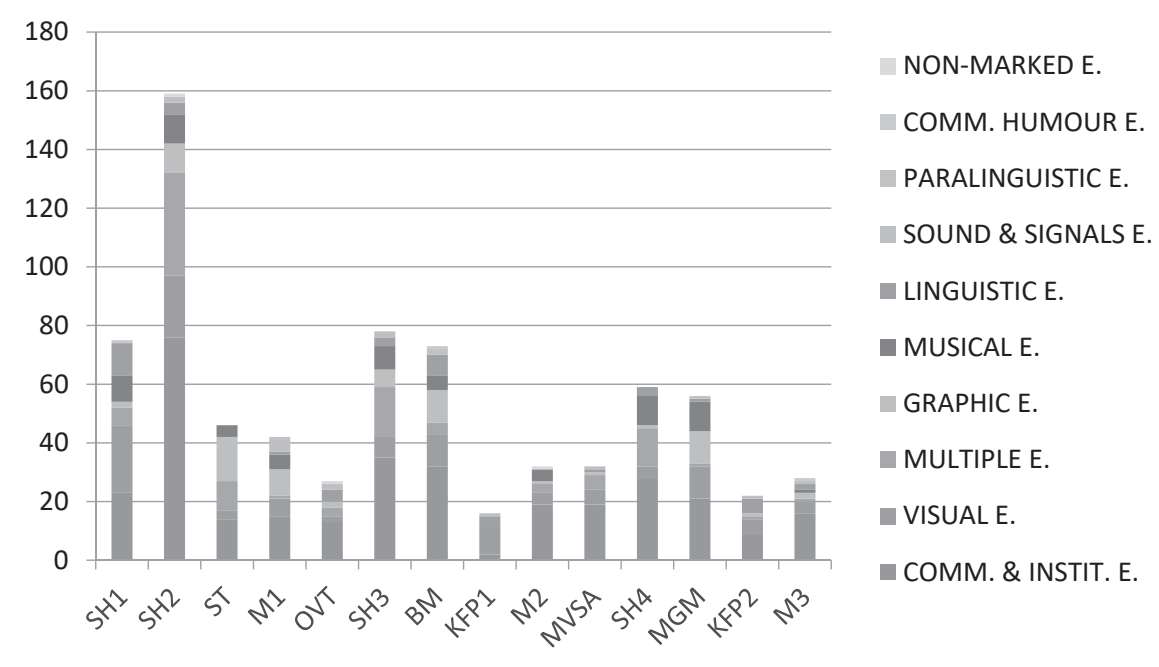

Graph 1 - Humorous elements per film.

Those categories with an inferior number of occurrences were recorded in the following categories: Paralinguistic Elements (4 cases), Non-marked Elements (3) and Community and Sense of Humour Elements (3 cases). This last category of humour is also known as Ethnic humour. This term makes reference to how certain communities might crack jokes by making fun of another community. This humour was avoided in these films to entertain the highest number of spectators as possible no matter where these might be from.

The non-marked category includes those humorous occurrences which cannot be easily classified. Given that only three out of 745 occurrences of this type were spotted, this small number demonstrates that almost all the intertextual humour found in these films could be classified, or in more accurate words, one can distinguish how the intertextual humour spotted in these films was specifically created. 


\subsection{Results obtained from the Dubbed Versions}

After pinpointing the humorous elements included in the original version animated feature films studied here there is a need to discuss how these were specifically dubbed for the Spanish-speaking audience from Spain.

The dubbing agents involved in the transfer of these films intervened in 415 occasions out of the total 745 occurrences spotted, which in mathematical terms is $55.7 \%$ translator participation, i.e. more than half of the compiled occurrences were translated into Spanish by transferring intertextuality in a varying degree and through several strategies. On the other hand, 330 occurrences were communicated through other codes which do not demand the intervention of translators or dubbing directors: These are the syntactic, mobility, photographic, iconographic and special effects (44.3\% of the compiled occurrences).

The literal translation strategy was chosen in 149 cases out of the total of 415 occurrences that involved translators' participation. Here, literality is understood as the transference of the content as it appears in the ST, and not a word per word transfer. These 149 cases were classified within the linguistic code representing $35.9 \%$ of the translated material.

Through the acoustic channel and linguistic code the Spanish audience receives 165 intertextual occurrences out of the total of 745 cases that were compiled. Besides, 79 occurrences were lost in the dubbing process and extra information was added in the translation of 17 cases within this channel and code. As a result, more intertextual cases are received by the Spanish audience than lost in the communication chain.

Within other codes which could demand a translation for the Spanish audience, written words on screen, i.e. graphic elements, have not been dubbed. Intertextuality was transferred without translation in 39 cases which means that aural language has compensated the lack of translation of posters, notes and language on screen. Adaptation helped transfer three cases and 77 texts (captions, Chaume 2012: 117) were omitted. As a result a high number of intertextual references are lost for the target audience. The adaptation of intertextual references written on screen could not communicate the references in two occasions. Domestication was not put into practice to transfer the graphic code through any of the three analysed techniques (adaptation, literality and omission). In total 42 intertextual occurrences were transferred but 79 were omitted.

Language can also be uttered through the musical code; however, in this corpus the intertextual content communicated through songs was literally translated into Spanish in only five cases. Omission did not mean the absence 
of the reference in one case and adaptation allowed the transfer of nine intertextual occurrences. In some occasions the use of translation techniques did not guarantee the transfer of intertextual references: Literal translation (four cases), omission (one case) and adaptation (nine cases). Domestication did not take place within the musical code. Most of the songs sang were kept in their original version. In fact, the target audience only receives 15 scarce intertextual occurrences which were translated into Spanish, whereas 14 cases were lost along the process.

\subsection{Examples}

Three examples belonging to the most relevant Humorous Elements groups in terms of a high number of compiled occurrences will be presented in this subsection to show the difficulties the dubbing team had to surmount and the strategies put into practice.

\subsubsection{Community-and-Institution Elements}

These types of elements depend on particular cultural aspects in order to trigger the humorous situation. In other words, these can be properly considered intertextual humorous occurrences since previous knowledge is essential to fully understand the joke on screen. In this example an English-speaking audience will easily relate the dialogue with this television series. In Spain, The Waltons was also broadcast, but many teenagers and children will not spot the allusive humour behind the animal's words in the film. In Spain this series was on television during the seventies and early eighties, which demonstrate how allusions from the past might not be recognised by all viewers. This dialogue in English is funny but the target audience might not get the joke.

For the dubbing team the translation of the sequence will not pose any obstacles. The literal translation transfers all but the humour. Also, a bad translation results in a confusing comment and the disappearance of a joke. Here, the young hedgehogs treat Verne (a turtle) as their uncle in the ST, something which was neglected during the dubbing of the scene. A few scenes later, RJ makes fun of Verne by calling him "uncle", which makes the viewer wonder why he has addressed him in this way, when in the first scene this family relation had been omitted in the dubbed version. However, tío, the Spanish word for uncle, is not present in the translated version. Here, incoherence in the translation of both scenes winds up neutralising two jokes. 


\begin{tabular}{|c|c|c|c|c|c|}
\hline \multirow{2}{*}{$\begin{array}{l}\text { General no. } \\
\text { I\&H-214 }\end{array}$} & \multirow{2}{*}{$\begin{array}{l}\text { Specific no. } \\
\text { OVT-4 }\end{array}$} & \multicolumn{2}{|c|}{ Film's Title } & \multirow[t]{2}{*}{$\begin{array}{l}\text { Time Code } \\
\text { Record }\end{array}$} & \multirow[t]{2}{*}{$\begin{array}{l}\text { Première } \\
\text { date in } \\
\text { U.S.A. and } \\
\text { Spain }\end{array}$} \\
\hline & & $\begin{array}{l}\text { Over the } \\
\text { Hedge }\end{array}$ & & & \\
\hline \multicolumn{2}{|c|}{ Type of Intertextuality } & \multicolumn{2}{|c|}{ Channel and Code } & \multicolumn{2}{|c|}{ Humoristic Element } \\
\hline \multicolumn{2}{|c|}{$\begin{array}{l}\text {-TV Allusion: } \\
\text { The Waltons (1971-1981) }\end{array}$} & \multicolumn{2}{|c|}{$\begin{array}{l}\text { 1) Acoustic Channel: } \\
\text { Linguistic Acoustic Code }\end{array}$} & \multicolumn{2}{|c|}{$\begin{array}{l}\text { 1) Community and } \\
\text { Institutions Elements }\end{array}$} \\
\hline \multicolumn{3}{|c|}{ ST } & \multicolumn{3}{|l|}{ TT } \\
\hline \multicolumn{3}{|c|}{$\begin{array}{l}\text { Verne: Good night, Heather. } \\
\text { Heather: Good night, Verne. } \\
\text { Verne: Good night, Ozzie. } \\
\text { Ozzie: Good night, Verne. } \\
\text { Verne: Good night, Lou. } \\
\text { Lou: Yeah, good night there Verne. } \\
\text { Verne: Night, Penny. } \\
\text { Penny: Good night. } \\
\text { Verne: Good night, Hammy. } \\
\text { Hammy: Good night, Verne. } \\
\text { Verne: Good night, Bucky. } \\
\text { Bucky: Good night. } \\
\text { Verne: Good night, Spike. } \\
\text { Spike: Good night, uncle Verne. } \\
\text { Verne: Good night, Quillo. } \\
\text { Quillo: Good night, uncle Verne. } \\
\text { Verne: Remember, when we wake up, } \\
\text { we've only got 273 days left till Winter. } \\
\text { Stella: That's enough, Verne. } \\
\text { Verne: Good night, [Whispering] } 273 .\end{array}$} & \multicolumn{3}{|c|}{$\begin{array}{l}\text { Verne: Buenas noches, Heather. } \\
\text { Heather: Buenas noches. } \\
\text { Verne: Buenas noches, Ozzie. } \\
\text { Ozzie: Buenas noches. } \\
\text { Verne: Buenas noches, Lou. } \\
\text { Lou: Que descanses, Verne. } \\
\text { Verne: Buenas noches, Penny. } \\
\text { Penny: Buenas noches. } \\
\text { Verne: Buenas noches, Hammy. } \\
\text { Hammy: Buenas noches. } \\
\text { Verne: Buenas noches, Piño. } \\
\text { Piño: Buenas noches. } \\
\text { Verne: Buenas noches, Puo. } \\
\text { Puo: Buenas noches. } \\
\text { Verne: Buenas noches, Pincho. } \\
\text { Pincho: Buenas noches. } \\
\text { Verne: Mañana solo quedarán } 273 \text { días } \\
\text { para el invierno. } \\
\text { Stella: Ya basta. } \\
\text { Verne: Buenas noches, (Susurra) } 273 .\end{array}$} \\
\hline \multicolumn{6}{|l|}{ Context } \\
\hline \multicolumn{6}{|c|}{$\begin{array}{l}\text { The animals go to sleep in their trunk. RJ (the main character) hears from a branch on } \\
\text { a tree how they say good night to each other as if they were family. }\end{array}$} \\
\hline \multicolumn{6}{|c|}{ Director(s') and/or Producer(s') Comments } \\
\hline \multicolumn{6}{|c|}{$\begin{array}{l}\text { The homage to the TV series The Waltons emphasises the fact that Verne has a family } \\
\text { whereas RJ sleeps by himself on a tree with a newspaper sheet as a blanket. }\end{array}$} \\
\hline
\end{tabular}

Table 3 - Example of how community-and-institution elements can create humour in Over the Hedge.

\subsubsection{Graphic Elements}

This occurrence is a clear example of how intertextual humour can be created through graphic language on the screen. In Megamind, the use of an ideological allusion triggers humour when its main character makes reference to Obama's 2008 campaign poster "Yes, we can" turned into "No, you can't" in 
this film. This negative form of the popular slogan appears under a picture of Megamind (the main character), which also imitates the black and blue picture Obama had taken for his campaign. The final effect is a parody, which shows this animated feature film's character's evil attitudes. Unfortunately, this joke was not translated into Spanish through an off-voice or subtitle. Despite this, the Spanish audience will probably remember this slogan which has also been commented on in the Spanish media.

\begin{tabular}{|c|c|c|c|c|c|}
\hline General no. & Specific no. & \multicolumn{2}{|l|}{ Film's Title } & $\begin{array}{l}\text { Time Code } \\
\text { Record }\end{array}$ & $\begin{array}{l}\text { Première } \\
\text { date in } \\
\text { U.S.A. and } \\
\text { Spain }\end{array}$ \\
\hline I\&H-455 & MGM-16 & \multicolumn{2}{|l|}{ Megamind } & $00: 23: 23$ & $\begin{array}{l}5 / 11 / 2010 \\
3 / 12 / 2010 \\
\end{array}$ \\
\hline \multicolumn{2}{|c|}{ Type of intertextuality } & \multicolumn{2}{|c|}{ Channel and Code } & \multicolumn{2}{|c|}{ Humoristic Element } \\
\hline \multicolumn{2}{|c|}{$\begin{array}{l}\text {-Ideological Allusion: } \\
\text { Person: Barack Obama } \\
\text { (1961- ) Politician, } \\
\text { currently the U.S.A.'s } \\
\text { president }\end{array}$} & \multicolumn{2}{|c|}{$\begin{array}{l}\text { 1) Visual channel: } \\
\text { Graphic visual code. Text. } \\
\text { Campaign poster }\end{array}$} & \multicolumn{2}{|c|}{ 1) Graphic elements } \\
\hline \multicolumn{3}{|l|}{ ST } & \multicolumn{3}{|l|}{ TT } \\
\hline \multicolumn{3}{|l|}{-} & \multicolumn{3}{|l|}{-} \\
\hline \multicolumn{6}{|l|}{ Context } \\
\hline \multicolumn{6}{|c|}{$\begin{array}{l}\text { Megamind took over the town hall. The mayor's office is the same as the US President's } \\
\text { Oval Office and the structure of the building exterior resembles the White House. In } \\
\text { one of the scenes there is a sign with a close-up picture of Megamind in a serious and } \\
\text { meditative pose with the slogan "No, You Can't." }\end{array}$} \\
\hline \multicolumn{6}{|c|}{ Director(s') and/or Producer(s') Comments } \\
\hline \multicolumn{6}{|c|}{$\begin{array}{l}\text { While the scene was being filmed, Obama won the elections for US President. It was } \\
\text { considered humorous to imitate the publicity used for his campaign, and so it was used } \\
\text { for advertising the film in New York, San Francisco and Los Angeles. }\end{array}$} \\
\hline \multicolumn{6}{|c|}{ Comments about intertextuality and humour } \\
\hline \multicolumn{6}{|c|}{$\begin{array}{l}\text { The campaign posters with the same background colours along with Obama's image } \\
\text { and pose were substituted with Megamind's on Metrocity's town hall building. This was } \\
\text { a recognisable allusion to Obama's campaign and made the U.S. adult public laugh. }\end{array}$} \\
\hline \multicolumn{6}{|c|}{ About the TT } \\
\hline \multicolumn{6}{|c|}{$\begin{array}{l}\text { In the target version, the visual allusion can be recognised if the public were familiar } \\
\text { with Obama's political campaign signs. The reference can be lost if this were not the } \\
\text { case. What eased the understanding of the intertextual humour was the "No, you } \\
\text { can't," a take on Obama's slogan, "Yes, we can." Given the briefness of the scene, no } \\
\text { information explaining the allusion in the target audiovisual text was included. }\end{array}$} \\
\hline
\end{tabular}

Table 4 - Example of how graphic elements can create humour in Megamind. 


\subsubsection{Multiple Elements}

This third example shows the combination of two humorous elements: Visual Elements and Community-and-Institution Elements. Visually, Barry's father's character is inspired on Sam Levenson's attire in The Graduate. This imitation together with Barry's attitude in Bee Movie recalls Dustin Hoffman's character in this 1967's film. Bee Movie uses other famous scenes of The Graduate to create humour which undoubtedly works among the adult audience. This scene required for its dubbing the omission and adaptation of some elements as can be read in the chart below:

\begin{tabular}{|c|c|c|c|c|c|}
\hline \multirow{2}{*}{$\begin{array}{l}\text { General no. } \\
\text { I\&H-297 }\end{array}$} & \multirow{2}{*}{$\begin{array}{l}\text { Specific no. } \\
\\
\text { BM-14 } \\
\text { BM-15 } \\
\end{array}$} & \multicolumn{2}{|l|}{ Film's Title } & \multirow{2}{*}{$\begin{array}{l}\text { Time Code } \\
\text { Record } \\
02 / 11 / 2007 \\
30 / 11 / 2007 \\
\end{array}$} & \multirow{2}{*}{$\begin{array}{l}\text { Première } \\
\text { date in } \\
\text { U.S.A. and } \\
\text { Spain }\end{array}$} \\
\hline & & Bee Movie & 00:09:45 & & \\
\hline \multicolumn{2}{|c|}{ Type of intertextuality } & \multicolumn{2}{|c|}{ Channel and Code } & \multicolumn{2}{|c|}{ Humoristic Element } \\
\hline \multicolumn{2}{|c|}{$\begin{array}{l}\text {-TV Allusion: } \\
\text { Person: Sam Levenson } \\
\text { (1911-1980) } \\
\text {-Cinematographic Allusion: } \\
\text { The Graduate (1967) }\end{array}$} & \multicolumn{2}{|c|}{$\begin{array}{l}\text { 1) Visual Channel: } \\
\text { Iconographic visual code } \\
\text { 2) Visual Channel: } \\
\text { Iconographic visual code }\end{array}$} & \multicolumn{2}{|c|}{$\begin{array}{l}\text { 1) Visual Elements } \\
\text { 2) Community-and- } \\
\text { Institution Elements }\end{array}$} \\
\hline \multicolumn{3}{|l|}{ ST } & \multicolumn{3}{|l|}{ TT } \\
\hline $\begin{array}{l}\text { Barry: You k } \\
\text { about it, ma) } \\
\text { right for me. } \\
\text { Martin: And } \\
\text { making ball } \\
\text { for a guy wit } \\
\text { Barry: Well, } \\
\text { Martin: Jane } \\
\text { to go into ho } \\
\text { Janet: Oh, Be } \\
\text { sometimes. } \\
\text { Barry: I'm no } \\
\text { Martin: You' } \\
\text { into honey. } \\
\text { Janet: You're } \\
\text { Barry: No on } \\
\text { Martin: Wait } \\
\text { for you! } \\
\text { Barry: I can } \\
\text { I'm gonna ge } \\
\text { Janet: Let's o } \\
\text { celebrate! }\end{array}$ & $\begin{array}{l}\text { ow, dad, the mo } \\
\text { ou were thinki } \\
\text { n animals? Th } \\
\text { a stinger. } \\
\text { o... } \\
\text { your son's not } \\
\text { ey! } \\
\text { ry, you are so f }\end{array}$ & $\begin{array}{l}\text { ore I think } \\
\text { ld just isn't } \\
\text { ng of what, } \\
\text { at's a bad job } \\
\text { sure he wants } \\
\text { unny } \\
\text { nny. } \\
\text { u're going } \\
\text { er! } \\
\text { er? } \\
\text { ne. } \\
\text { sticks I have } \\
\text { ant right now. } \\
\text { honey and }\end{array}$ & \multicolumn{3}{|c|}{$\begin{array}{l}\text { Barry: Es que no sé, verás, cuanto más lo } \\
\text { pienso, a lo mejor lo de la miel no está } \\
\text { hecho para mí. } \\
\text { Martin: ¿Y a qué quieres dedicarte? ¿A } \\
\text { hacer globos y cometas? No es trabajo } \\
\text { para un tío con aguijón. } \\
\text { Barry: Bueno, no... } \\
\text { Martin: Janet, ¡tu hijo no está seguro de } \\
\text { querer dedicarse a la miel! } \\
\text { Janet: Oh, Barry, cómo te gusta gastar } \\
\text { bromas. } \\
\text { Barry: No es una broma ¡de verdad! } \\
\text { Martin: Se acabó la broma. Vas a dedicarte } \\
\text { a la miel. ¡Nuestro hijo será removedor! } \\
\text { Janet: ¡Vas a ser removedor! } \\
\text { Barry: Pero... ¿queréis escucharme? } \\
\text { Martin: Heredarás la pala que usó tu } \\
\text { padre. } \\
\text { Barry: Es inútil, no hacen ni caso. ¡Me voy } \\
\text { a tatuar el trasero! } \\
\text { Janet: ¡Serviré unas copitas de miel y a } \\
\text { celebrarlo! }\end{array}$} \\
\hline
\end{tabular}




\begin{tabular}{|c|c|}
\hline $\begin{array}{l}\text { Barry: Maybe I'll pierce my thorax. Shave } \\
\text { my antennae. } \\
\text { Martin: To honey! } \\
\text { Barry: Shack up with a grasshopper. Get } \\
\text { a gold tooth; start calling everybody } \\
\text { "dawg"! } \\
\text { Martin: I'm so proud. }\end{array}$ & $\begin{array}{l}\text { Barry: Voy a hacerme un piercing en el } \\
\text { tórax. } \\
\text { Martin: ¡Por la miel! } \\
\text { Barry: Me raparé las antenas,... } \\
\text { Janet: ¡Por la miel! } \\
\text { Barry: ...me liaré con una avispa y me } \\
\text { dejaré cresta y llamaré a todo el mundo } \\
\text { tronco. } \\
\text { Martin: ¡Qué orgulloso estoy! }\end{array}$ \\
\hline \multicolumn{2}{|l|}{ Context } \\
\hline \multicolumn{2}{|c|}{$\begin{array}{l}\text { Barry is not sure about what he wants to be the rest of his life. That is why he decides } \\
\text { to talk to his father about it but his father does not listen. }\end{array}$} \\
\hline \multicolumn{2}{|c|}{ Director(s') and/or Producer(s') Comments } \\
\hline \multicolumn{2}{|c|}{$\begin{array}{l}\text { Barry's father, Martin, is inspired by the actor, Sam Levenson, and the wardrobe used in } \\
\text { the film, The Graduate. }\end{array}$} \\
\hline \multicolumn{2}{|l|}{ Comments about intertextuality and humour } \\
\hline \multicolumn{2}{|c|}{$\begin{array}{l}\text { The scene where Martin has a conversation with Barry telling him to follow his } \\
\text { footsteps in Honex is ironic and achieves a humorous effect in this way. Barry's reaction } \\
\text { is also a take on Dustin Hoffman's rebellious character. }\end{array}$} \\
\hline \multicolumn{2}{|l|}{ About the TT } \\
\hline \multicolumn{2}{|c|}{$\begin{array}{l}\text { An intertextual translation using visual content was not necessary. However, the } \\
\text { dialogue did need dubbing. The three humorous fragments required the omission of } \\
\text { some elements and the inclusion of some amplification strategies. }\end{array}$} \\
\hline
\end{tabular}

Table 5 - Example of how multiple elements can create humour in Bee Movie.

\section{Conclusions}

The analysis of the intertextual humour included in the fourteen studied films produced by DreamWorks has revealed that this humour is created mainly thanks to elements which belong to the community and institutions from the source culture. Apart from these elements, visual, graphic and multiple elements also trigger laughter in these films.

Intertextual humour is also obtained through comic situations which escape reality. In a way, animation allows the introduction of narrative sequences far from the reality shown in real action films. Animation works as a canvas where anything can happen becoming a space for fantasy to occur even in a nonsensical manner.

Another intertextual resource observed in the compiled humorous scenes has to do with the use of slapstick in order to get the youngest to laugh. These scenes remind the eldest of their cartoon classics: Hanna-Barbera, UPA and famous animators such as Tex Avery. The translators must have a huge 
knowledge of the source language's culture and history in order to succeed in this undertaking, something which must not be overlooked during their training.

To create the incongruity required to make the audience laugh, DreamWorks uses parody and anachronisms. By imitating other previously created materials and subverting their original features, Dreamworks breaches the audience's expectations triggering laughter. Anachronisms also create this humorous effect since there is a mixture of ideas and objects from past and present.

Breaching expectations is precisely what needs to be achieved in the dubbing process even if the polysemiotic nature of the text might seem to make this process impossible. Image and dialogue must interact and despite the constraints imposed by the audiovisual text, the intertextual humour included in these films has been transferred to entertain the target audience by mainly putting into practice literal translation techniques. This fact demonstrates how the Spanish audience has assimilated the American culture to the point that many intertextual references stop being an obstacle for the understanding of the hidden/allusive joke.

\section{References}

Antonopoulou, Eleni. (2004) "Humor Theory and Translation Research: Proper Names in Humorous Discourse." Humor, the International Journal of Humor Research 17:3, pp. 219-255.

ATtARDO, Salvatore. (1989) "A multiple-level analysis of jokes." Humor, the International Journal of Humor Research 2:4, pp. 438-439.

ATTARDO, Salvatore \& Victor Raskin. (1991) "Script Theory revis(it)ed: Joke Similarity and Joke Representation Model." Humor, the International Journal of Humor Research 4:3/4, pp. 293-347.

AtTARDO, Salvatore. (1994) Linguistic Theories of Humor. Berlin \& New York: Mouton de Gruyter.

BAsSnetT, Susan. (1980) Translation Studies. London \& New York: Routledge. Ben-Porat, Ziva. (1978) "The Poetics of Literary Allusion." PTL 1, pp. 105-128. BRU DZIAK, Ewelina. (2011). Translation Strategies and Techniques in Audiovisual Translation of Humor: Analysis of "Shrek 2" and "Ice Age." Gdańsk: Grin Verlag. Chaume, Frederic. (2012) Audiovisual Translation: Dubbing. Manchester \& New York: St. Jerome.

ChiAro, Delia. (1992) The Language of Jokes. Analysing Verbal Play. London \& New York: Routledge.

ChiAro, Delia. (2006) "Verbally Expressed Humour on Screen: Reflections on Translation and Reception." The Journal of Specialised Translation 6, pp. 198-207. 
ChiARO, Delia. (2008) "Verbally Expressed Humor and Translation." In: Raskin, Victor (ed.) 2008. The Primer of Humour Research. Berlin \& New York: Mouton de Gruyter, pp. 569-610.

Chiaro, Delia. (2010) Translation and Humour, Humour and Translation in Translation, Humour and Literature Vol.1. London \& New York: Continuum International Publishing Group.

CritChley, Simon. (2002) On Humour. London: Routledge.

CUÉlLAR, Jana \& Andrea GarCía. (2004) "Cultura y humor: traductores al borde de un ataque de nervios." Linguax. Revista de lenguas aplicadas 2, pp. 1-30.

DEL CORRAL, Irene. (1988) "Humor: When do We Lose it?" Translation Review 27, pp. 25-27.

ECO, Umberto. (1981 [1979]). Lector in fabula. La cooperación interpretativa en el texto narrativo. Barcelona: Lumen.

Even-ZOHAR, Itamar. (1997) "The Making of Culture Repertoire and Role of Transfer." Target 9:2, pp. 355-363.

FUENTES, Adrián. (1998) "Humor, cine y traducción." In: Félix Fernández, Leandro \& Emilio Ortega Arjonilla (eds.) 1998. Actas de las II Jornadas Internacionales de Traducción e Interpretación de la Universidad de Málaga 17-20 de marzo de 1997. II Estudios sobre Traducción e Interpretación. Tomo II. Málaga: Universidad de Málaga \& Diputación Provincial de Málaga, pp. 665-671.

FUENTES, Adrián. (2001) "Estudio empírico sobre recepción del humor audiovisual." In: Lorenzo, Lourdes \& Ana María Pereira (eds.) 2001. Traducción subordinada (II). El subtitulado (inglés-español/galego). Vigo: Servizo de Publicacións da Universidade de Vigo, pp. 69-84.

GoATly, Andrew. (2012) Meaning and Humour. Cambridge: Cambridge University Press.

Leppihalme, Ritva. (1997) Culture Bumps. An Empirical Approach to the Translation of Allusions. Clevedon: Multilingual Matters.

LÓPEZ GONZÁLEZ, Rebeca Cristina. (2015) La alusión como fuente de creación de humor y su traducción: análisis del cine de animación de DreamWorks (20012012). Vigo: Universidade de Vigo. Tesis doctoral inédita.

MARTínez SieRra, Juan José. (2008) Humor y traducción: Los Simpson cruzan la frontera. Castellón: Universitat Jaume I.

MaYORAL, Roberto; Dorothy Kelly \& Natividad Gallardo. (1988) "Concept of Constrained Translation. Non-Linguistic Perspectives of Translation.” Meta XXXIII:3, pp. 356-367.

NASH, Walter. (1987 [1985]) The Language of Humour. London \& New York: Longman.

NORD, Christiane. (1997) Translation as a Purposeful Activity. Functionalist Approaches Explained. Manchester: St Jerome Publishing. 
NORRICK, Neal R. (1993) Conversational Joking Humor in Everyday Talk. Bloomington $\&$ Indianapolis: Indiana University Press.

RASKIN, Victor. (1979) "Semantic Mechanisms of Humor." In: Chiarello, Christine et al. (eds.) 1979. Proceedings of the Fifth Annual Meetings of the Berkeley Linguistics Society. Berkeley, California: University of California, pp. 325-335.

RASKIN, Victor. (1985) Semantic Mechanisms of Humor. Dordrecht, Boston \& Lancaster: D. Reidel Publishing Company.

RitchiE, Graeme. (2004) The Linguistic Analysis of Jokes. London \& New York: Routledge.

RUCH, Willibald; Salvatore Attardo \& Victor Raskin. (1993) "Toward an Empirical Verification of the General Theory of Verbal Humor." Humor, the International Journal of Humor Research 6:2, pp. 123-136.

SPANAKAKI, Katia. (2007) "Translating Humor for Subtitling." Translation Journal $11: 2$.

VAndaele, Jeroen. (1999) "Each Time We Laugh. Translated Humor in Screen Comedy." In: Vandaele, Jeroen (ed.) 1999. Translation and the (Re)location of Meaning. Selected papers of the CETRA Research Seminars in Translation Studies 1994-1996. Leuven: KUL Publications, pp. 237-272.

VANDAELE, Jeroen. (2001) “'Si Sérieux s'abstenir' Le discours sur l'humour traduit." Target 13:1, pp. 29-44.

VANDAELE, Jeroen. (2002a) "Introduction (Re-)Constructing Humour: Meanings and Means." The Translator 8:2, pp. 149-172.

VANDAELE, Jeroen. (2002b) "Humor Mechanisms in Film Comedy: Incongruity and Superiority." Poetics Today 23:2, pp. 221-249.

VAndaElE, Jeroen. (2010) "Humor in Translation." In: Gambier, Yves \& Luc Van Doorslaer (eds.) 2010. Handbook of Translation Studies Vol. 1. Antwerp: John Benjamins Publishing Company, pp. 147-152.

Venuti, Lawrence. (1995) The Translator's Invisibility. A History of Translation. London \& New York: Routledge.

YÉBENES, Pilar. (2002) Cine de animación en España. Barcelona: Ariel. 


\section{BIONOTE / NOTA BIOGRÁFICA}

REBECA CRISTINA LÓPEZ GONZÁLEZ is currently a full-time Research Lecturer at the University of Vigo, Spain (Translation and Linguistics Department). Her education and working experience includes a B.A. in Translation and Interpreting granted by the University of Vigo, Galicia, Spain. She is a certified Legal Translator since 2003, and obtained a B.A. in Education as well as a Master's Degree in Secondary Compulsory Education, O and A-level, Vocational School and Teaching Foreign Languages in 2004. She has recently obtained her $\mathrm{PhD}$ in Translation (2015). Her fields of interest are, among others, the translation and research of Audiovisual Translation, the translation of Literature and Folklore, Children's Literature and cultural aspects regarding Translation.

REBECA CRISTINA LÓPEZ GONZÁlEZ imparte su docencia a tiempo completo en la Universidade de Vigo, Galicia (Departamento de Traducción y Lingüística). Es licenciada en Traducción e Interpretación por la Universidade de Vigo. Ha trabajado como traductora intérprete jurada desde 2003 y se ha diplomado en Magisterio (Educación Primaria) (2008). Cuenta con el Máster para el Profesorado desde 2004 y recientemente ha defendido su tesis doctoral en Traducción Audiovisual y Cine de Animación en 2015. Sus líneas de investigación incluyen, entre otras, el ámbito de la Traducción Audiovisual, la Traducción de Literatura y Folclore, Literatura Infantil y Juvenil y la traducción de aspectos culturales. 
